\title{
How can NIRS method be used to predict in situ crude protein and neutral detergent fibre degradation in herbage?*
}

\author{
S. Andrés ${ }^{1,3}$, A. Calleja ${ }^{1}$, R. Peláez ${ }^{1}$, A.R. Mantecón ${ }^{2}$ and F.J. Giráldez ${ }^{2}$ \\ ${ }^{1}$ Departamento de Producción Animal I Universidad de León \\ E-24071 León, Spain \\ ${ }^{2}$ Estación Agrícola Experimental, CSIC \\ Apartado 788, E-24080 León, Spain
}

(Received 12 May 2005; accepted 17 October 2005)

\begin{abstract}
The near infrared (NIR) spectra of 62 herbage samples were used to predict the in situ degradability parameters of crude protein (CP) and neutral detergent fibre (NDF). Moreover, the NIR spectra of the incubation residues generated during this experiment were also obtained in order to estimate their chemical composition and then calculate the kinetic and degradability parameters of the NDF and $\mathrm{CP}$ using these estimated data. Thus, the results obtained by means of these two different procedures could be compared to those achieved with the reference method (incubation residues analysed by wet analytical methods). The most accurate results were obtained when the chemical data of the incubation residues were estimated using their NIR spectra. Nevertheless, it is less laborious to estimate the degradability parameters directly from the NIR spectra of the original herbage samples.
\end{abstract}

KEY WORDS: degradability, residues, chemical composition, NIRS, forages

\section{INTRODUCTION}

The ruminant feeding systems require information about the chemical composition of the feedstuffs and also about other feed attributes, such as the degradation kinetics in the rumen, in order to asses the nutrient supply to the animal (Huntington and Givens, 1995). The nylon bag technique is considered as a reference method to estimate the extent of protein degradation in the rumen. Nevertheless, despite being regularly employed, this method generates a large number of feed residues, which

\footnotetext{
* Supported by the Spanish Ministry of Science and Technology, Project IFD97-0776

${ }^{3}$ Corresponding author: e-mail: dp1sal@unileon.es
} 
need to be analysed by wet and expensive analytical methods to calculate the amount of feed fraction degraded at each time period. Moreover, the amount of residue remaining after the incubation is too limited to perform many different analyses in duplicate (Kański and Kowalski, 2001). Therefore, to find a faster, cheaper, less laborious and at the same time feasible, repeatable and reliable alternative procedure for reducing the disadvantages of the in situ method would be desirable.

In this sense, it is well known the potential of near infrared spectroscopy to predict accurately DM and CP degradability parameters using the near infrared (NIR) spectra of the original forage samples (Andrés et al., 2005a). On the other hand, other studies have proved that NIRS method can accurately estimate the CP (Reeves III et al., 1991; Berzaghi et al., 1997; Kański and Kowalski, 2001), acid detergent fibre (ADF) and NDF (Berzaghi et al., 1997) concentration of the incubation residues. These chemical data can be used to calculate the extent of disappearance at different times, so the kinetic parameters can be estimated fitting these data to an exponential model. This procedure requires obtaining the incubation residues of the samples. However it reduces the number of wet analyses when a large number of residues is generated in the same degradation study.

Nevertheless, there is hardly any information about which of the two methods (NIR spectra of the original samples vs NIR spectra of the incubation residues) provides more accurate estimates of the degradability parameters of the feedstuffs. This study was implemented to compare the accuracy of prediction of the $\mathrm{CP}$ and NDF degradability parameters of botanically complex herbage samples when the NIR spectra of both the original samples and the incubation residues were used.

\section{MATERIAL AND METHODS}

\section{Feed samples}

This study was carried out using 62 botanically complex herbage samples harvested from permanent meadows located across the mountains of León (Northwest Spain). Samples were oven dried at $60^{\circ} \mathrm{C}$ and then ground to pass through a 4-mm screen. These coarse samples were used for the nylon bag technique. Furthermore, a sub-sample was ground to pass through a 1-mm screen, to be subsequently used for chemical analyses. Both the samples and the analysis are described in Andrés et al. (2005b).

\section{Nylon bag technique (in situ degradability)}

The degradation kinetics of the herbage samples were measured using three non-productive Holstein-Friesian cows fitted with a rumen cannula. The procedure used and the resulting kinetic parameters are reported in Andrés et al. (2005a,c). 


\section{Near infrared spectroscopy}

The herbage samples were scanned at $2 \mathrm{~nm}$ intervals over the NIR spectral range (1100 to $2500 \mathrm{~nm}$ ) as described by Andrés et al. (2005b). Williams (2001) suggested that two thirds of the whole sample set should be used for calibration purposes. According to this fact, the NIR spectra of 42 herbage samples were used to develop prediction equations for the in situ degradability parameters by means of partial least squares regression (PLSR). The external validation was completed by using the NIR spectra of the remaining samples (20) to estimate, directly, both the extent of disappearance and the potential $(\mathrm{a}+\mathrm{b})$ or effective degradability (ED) of CP and NDF fractions of each one. Different equations attending to different mathematical treatments of the spectra were generated, so the model with the highest predictability for each parameter was selected on the basis of minimizing the standard error of prediction (SEP) obtained for these 20 samples. This procedure for the estimation of the in situ data was named direct method.

The residues that had enough matter after the incubation period to be scanned were analysed by NIRS method in the same way as the original herbage samples. Thus, the NIR spectra corresponding to the incubation residues $(n=314)$ of the 42 herbage samples were used in the development of the prediction equations for the estimation of the CP and NDF concentrations. The NIR spectra of the rest of the incubation residues $(n=180)$, that is to say, those corresponding to the 20 remaining samples, were used to estimate their $\mathrm{CP}$ and NDF proportions. Finally, the extent of disappearance for these 20 samples were calculated from these estimated data and the exponential model proposed by Dhanoa (1988) was fitted. Thus, the kinetic parameters $(a, b, c$ and $L)$ could be predicted and the potential $(\mathrm{a}+\mathrm{b})$ and effective (ED) degradability of the CP and NDF fractions calculated. This procedure for the estimation of the in situ data was named residue method.

Finally the estimated data obtained by the direct and residue methods were compared with those of the reference method (incubation residues of the in situ method analysed with wet analytical procedures) by using different statistical procedures. First of all, it was verified whether the differences were statistically different from zero (PROC MEANS of SAS, 1988). Moreover, the coefficient of correlation (R), the coefficient of concordance $(\rho)$, the mean square of the differences (MSD) and the Theil decomposition of the last mentioned were calculated according to Dhanoa et al. (1999).

\section{RESULTS AND DISCUSSION}

The range, mean value and standard deviation (SD) of the in situ degradability parameters of the herbage samples are shown in Table 1. In general, the differences 
observed between the mean and the SD for each parameter in both sets were less than 10 and $25 \%$, respectively. Therefore, it could be considered that the herbage samples used to perform the NIR equations -calibration set- were similar to those in the validation procedure (Moya et al., 1995).

TABLE 1

Range, mean and standard deviation of extent of disappearance (DCP, DNDF), potential $\left(a+b_{C P}\right.$, $\mathrm{a}+\mathrm{b}_{\mathrm{NDF}}$ ) and effective degradability (EDCP, EDNDF) of CP and NDF of herbage samples (reference method)

\begin{tabular}{|c|c|c|c|c|c|c|}
\hline \multirow{2}{*}{ Indices } & \multicolumn{3}{|c|}{ Calibration set $(n=42)$} & \multicolumn{3}{|c|}{ Validation set $(n=20)$} \\
\hline & range & mean & SD & range & mean & SD \\
\hline \multicolumn{7}{|c|}{ In situ CP degradability, \% of CP } \\
\hline $\mathrm{DCP}_{12}$ & $40.6-77.9$ & 67.6 & 8.14 & $45.1-77.3$ & 65.1 & 7.59 \\
\hline $\mathrm{DCP}_{24}$ & $57.6-88.9$ & 77.6 & 6.97 & $60.0-87.4$ & 75.8 & 7.45 \\
\hline $\mathrm{DCP}_{48}$ & $65.0-93.2$ & 85.0 & 5.61 & $68.9-90.9$ & 83.4 & 6.14 \\
\hline $\mathrm{a}+\mathrm{b}_{\mathrm{CP}}$ & $74.6-95.5$ & 88.4 & 4.29 & $75.9-92.5$ & 87.0 & 4.60 \\
\hline $\mathrm{EDCP}_{0.02}$ & $61.6-85.2$ & 75.8 & 4.84 & $60.9-83.4$ & 74.6 & 5.41 \\
\hline $\mathrm{EDCP}_{0.06}$ & $43.7-73.3$ & 62.0 & 6.05 & $47.6-72.2$ & 61.0 & 5.38 \\
\hline \multicolumn{7}{|c|}{ In situ NDF degradability, \% of NDF } \\
\hline $\mathrm{DNDF}_{12}$ & $18.9-65.7$ & 38.0 & 13.16 & $17.2-51.8$ & 33.3 & 10.08 \\
\hline $\mathrm{DNDF}_{24}$ & $27.6-80.0$ & 51.0 & 13.21 & $29.1-63.1$ & 45.5 & 10.13 \\
\hline $\mathrm{DNDF}_{48}$ & $39.0-81.0$ & 63.8 & 11.21 & $40.4-75.6$ & 59.2 & 9.33 \\
\hline $\mathrm{a}+\mathrm{b}_{\mathrm{NDF}}$ & $59.6-84.0$ & 72.6 & 7.25 & $56.2-77.2$ & 69.7 & 6.00 \\
\hline $\mathrm{EDNDF}_{0.02}$ & $36.3-66.2$ & 51.9 & 8.89 & $34.5-62.4$ & 49.1 & 7.58 \\
\hline $\mathrm{EDNDF}_{0.06}$ & $20.2-46.5$ & 33.6 & 7.76 & $20.6-45.7$ & 31.1 & 7.08 \\
\hline
\end{tabular}

$\mathrm{DCP}, \mathrm{DNDF}=$ disappearance rates at 12,24 and $48 \mathrm{~h}$, respectively; $\mathrm{a}+\mathrm{b}_{\mathrm{CP}}, \mathrm{a}+\mathrm{b}_{\mathrm{NDF}}=$ potential degradability; EDCP or EDNDF = effective degradability at different rumen passage rates $(0.02$ and $0.06 \mathrm{~h}^{-1}$ )

Table 2 shows the chemical data corresponding to the incubation residues. The results of the NIR prediction equations developed to estimate their chemical composition are summarised in Table 3.

TABLE 2

Range, mean and standard deviation of $\mathrm{CP}$ and NDF concentrations ( $\left.\mathrm{g} \mathrm{kg}^{-1} \mathrm{DM}\right)$ corresponding to the incubation residues (WET analysis)

\begin{tabular}{lccccccc}
\hline \multirow{2}{*}{ Indices } & \multicolumn{3}{c}{ Calibration set $(\mathrm{n}=314)$} & & \multicolumn{3}{c}{ Validation sample set $(\mathrm{n}=180)$} \\
\cline { 2 - 4 } & range & mean & SD & & range & mean & SD \\
\hline CP & $39-194$ & 94 & 42.7 & & $40-193$ & 87 & 38.7 \\
\hline NDF & $564-863$ & 761 & 72.3 & & $592-874$ & 768 & 65.5 \\
\hline
\end{tabular}


TABLE 3

Calibration and validation statistics of the prediction equations developed to estimate the $\mathrm{CP}$ and NDF concentrations $\left(\mathrm{g} \mathrm{kg}^{-1} \mathrm{DM}\right)$ of the incubation residues by means of their NIR spectra

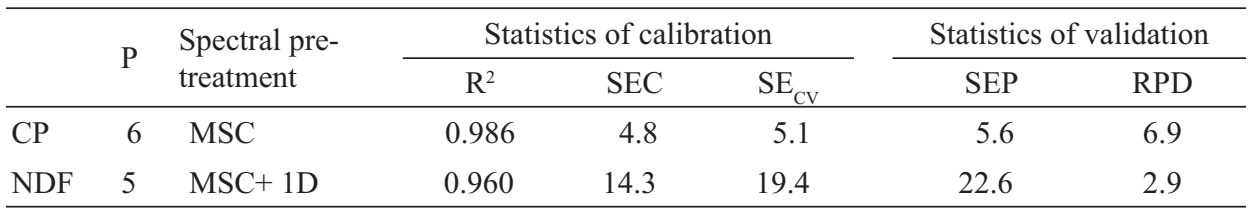

$\mathrm{MSC}+1 \mathrm{D}$ : multiplicative scatter correction and first order derivative; $\mathrm{SEC}, \mathrm{SE} \mathrm{CV}_{\mathrm{S}}, \mathrm{SEP}$ : standard error of calibration, cross-validation and prediction, respectively; RPD: ratio performance deviation calculated as SD/SEP

Williams and Sobering (1993) suggested that the statistic RPD (ratio performance deviation), which is the ratio of the standard deviation (SD) of the reference values to the standard error of prediction (SEP), should be larger than 2.5 to admit the accuracy of prediction of any equation as acceptable. As can be observed, the CP and NDF concentrations of the 180 incubation residues corresponding to the 20 herbage samples could be predicted successfully $\left(\mathrm{R}^{2}>0.90\right.$; RPD $\left.>2.5\right)$ by means of NIRS method.

Extent of disappearance, potential and effective degradability of CP and NDF fractions estimated using both direct and residue methods were compared to the data obtained with the reference method, as shown in Tables 4 and 5.

As far as CP degradability is concerned, the differences between the direct or residue method and the reference method were not statistically different from zero $(\mathrm{P}>0.05)$ in any case. In agreement with this fact, the Theil decomposition of the differences verified that the higher proportion of the MSD was due to unexplained variance (Table 4). However, the extent of disappearance at different times $\left(\mathrm{DCP}_{12}\right.$, $\mathrm{DCP}_{24}$ and $\left.\mathrm{DCP}_{48}\right)$, the potential $\left(\mathrm{a}+\mathrm{b}_{\mathrm{CP}}\right)$ and the effective $\left(\mathrm{EDCP}_{0.02}, \mathrm{EDCP}_{0.06}\right)$ degradability of the $\mathrm{CP}$ fraction estimated using the residue method were more similar to those of the reference method, as can be deduced from the higher R and $\rho$ coefficients and the lower MSD (Table 4).

The results obtained in the present study seem to indicate that the CP degradability parameters were more accurately predicted by using the residue method than by the direct method. This procedure only requires the quantification of the $\mathrm{N}$ present in the incubation residues by NIRS method. This is possible thanks to the close relationship existing between the absorbance of the molecular bonds in which $\mathrm{N}$ is implicated and the $\mathrm{N}$ concentration measured by the Kjeldhal method (Deaville and Flinn, 2000). It has to be remarked that the incubation residues were frozen at $-30^{\circ} \mathrm{C}$ for $24 \mathrm{~h}$ to remove any microbial cells adhering to the herbage particles (Andrés et al., 2005a), so these results were not supposed to be affected by this source of contamination. 


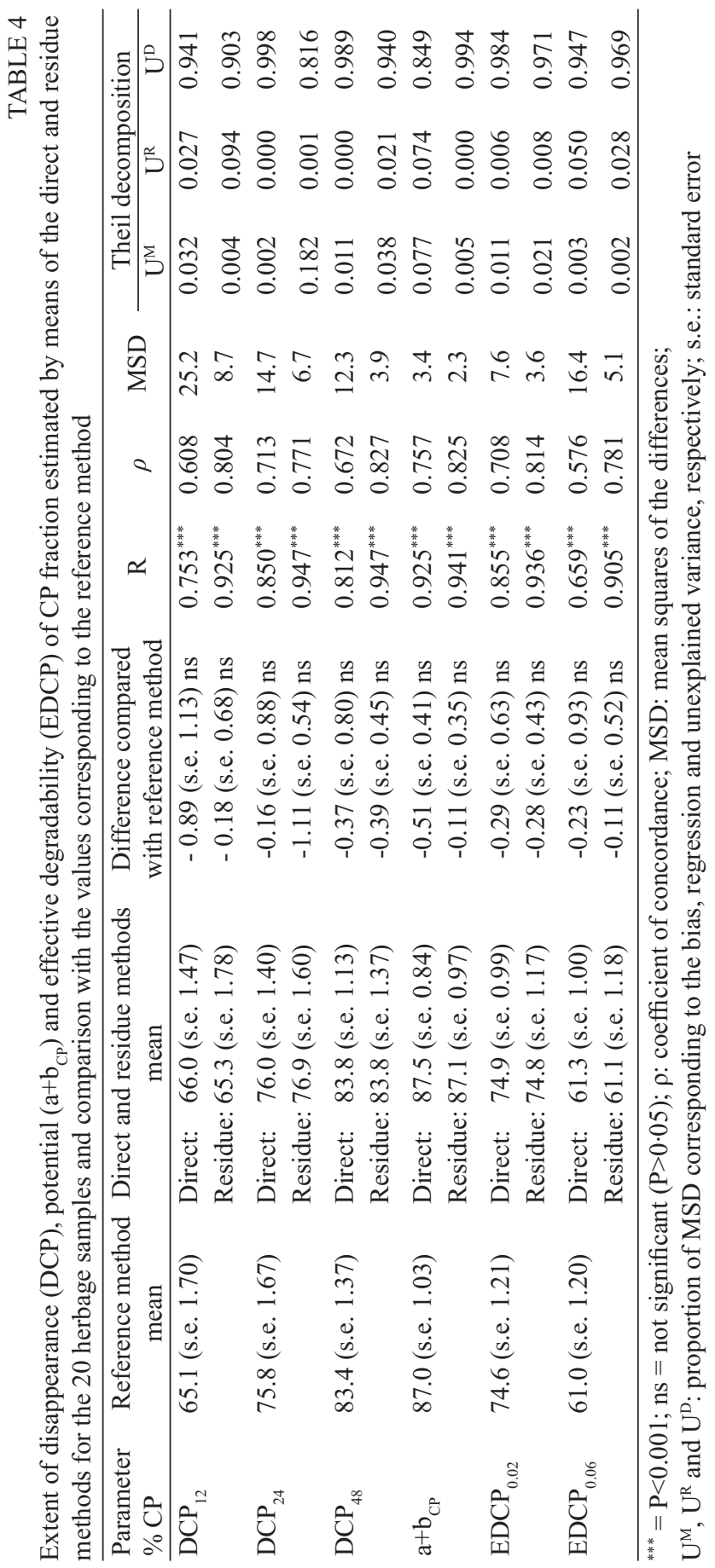


However, if the CP degradability parameters are predicted directly using the NIR spectra of the original herbage samples (direct method), not only the quantification of the $\mathrm{N}$ present in the original herbage samples is required, but probably also the identification of the molecular structure of the proteins, as this influences the CP degradation of the forages (Messman et al., 1994). It is well known that this aspect could be taken into account by the NIR spectra (Meng and Ma, 2001). Nevertheless, it is obvious that all this complexity of factors produces less accurate estimates of the CP degradability parameters by NIRS method (Table 4).

As far as NDF fraction is concerned (Table 5) neither direct nor residue method showed differences statistically different from zero $(\mathrm{P}>0.05)$ with the reference method. The Theil decomposition of the differences corroborates this fact, since the vast majority was due to random unexplained variance (Table 5). Moreover the higher $\mathrm{R}$ and $\rho$ coefficients and the lower MSD obtained for the residue method indicate that the extent of disappearance $\left(\mathrm{DNDF}_{12}, \mathrm{DNDF}_{24}\right.$ and $\left.\mathrm{DNDF}_{48}\right)$ and the potential $\left(\mathrm{a}+\mathrm{b}_{\mathrm{NDF}}\right)$ degradability were more similar to those of the reference method when they were estimated using the NIR spectra of the incubation residues. Nevertheless, $\mathrm{EDNDF}_{0.02}$ and $\mathrm{EDNDF}_{0.06}$ predictions using the NIR spectra of the original herbage samples (direct method) were, at least, as accurate as those obtained with the residue procedure (Table 5).

It is well known that NIRS method can take into account information about the different structural carbohydrates or the chemical bonds existing among them or with the lignin, so the degradability of NDF fraction can be estimated by means of the spectra corresponding to the original herbage samples. However, as stated beforehand for the $\mathrm{CP}$ fraction, all this information required by the direct procedure give rise to less accurate estimates of the NDF degradability parameters than the residue method, where NIRS method was used only to quantify the NDF fraction in the incubation residues (Table 5).

Finally it must be pointed out that the degradability of any constituent $(\mathrm{CP}$ or NDF) not only depend on the forage itself, but also on its interaction with the diet and some other animal dependent factors such as level of intake. These factors cannot be considered by the NIR spectra of the forage, and hence by the direct procedure. On the contrary, according to the residue procedure only the chemical composition of the residues has to be estimated by NIRS, so this method will be as accurate as this prediction is (Table 3 ). This is the reason why the residue method works better for the CP degradability parameters (Table 4) than for those related with the NDF fraction (Table 5). 


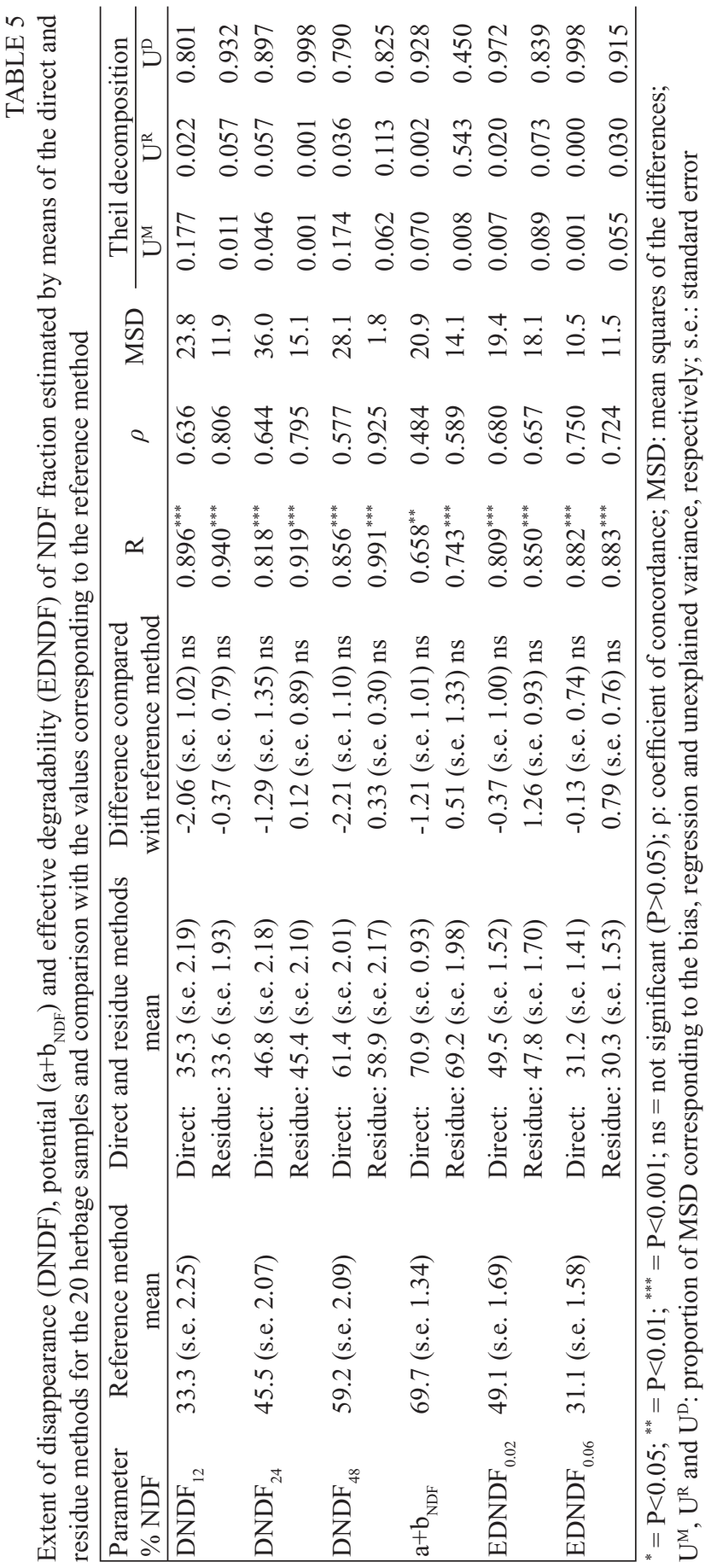




\section{CONCLUSIONS}

Near infrared spectroscopy accurately estimated the chemical composition of the incubation residues of the herbage samples. Generally speaking, the degradability parameters of the $\mathrm{CP}$ and NDF fractions estimated using these chemical data were more similar to those of the reference method than the parameters estimated directly from the NIR spectra of the original herbage samples. Nevertheless, this slight improvement does not seem to justify the increment in work that will be derived from the in situ incubations of all the samples with the object of obtaining all the incubation residues. It seems more convenient to estimate the degradability parameters directly from the NIR spectra of the original herbage samples without the need for in situ incubations.

\section{ACKNOWLEDGEMENTS}

S. Andrés is grateful to the "Junta de Castilla y León", Spain, for financial assistance under a pre-doctoral grant.

\section{REFERENCES}

Andrés S., Calleja A., López S., Mantecón A.R., Giráldez F.J., 2005a. Nutritive evaluation of herbage from permanent meadows by near infrared reflectance spectroscopy 2. Prediction of crude protein and dry matter degradability. J. Sci. Food Agr. 85, 1572-1579

Andrés S., Giráldez F.J., López S., Mantecón A.R., Calleja A., 2005b. Nutritive evaluation of herbage from permanent meadows by near infrared reflectance spectroscopy 1. Prediction of chemical composition and in vitro digestibility. J. Sci. Food Agr. 85, 1564-1571

Andrés S., Giráldez F.J., González J.S., Peláez R., Prieto N., Calleja A., 2005c. Prediction of aspects of neutral detergent fibre digestion of forages by chemical composition and near infrared reflectance spectroscopy. Aust. J. Agr. Res. 56, 187-193

Berzaghi P., Cozzi G., Andrighetto I., 1997. The use of near infrared analysis for in situ studies. J. Dairy Sci. 80, 3263-3270

Deaville E.R., Flinn P.C., 2000. Near infrared (NIR) spectroscopy: an alternative approach for the estimation of forage quality and voluntary intake. In: D.I. Givens, E. Owen, R.F.E. Oxford, H.M. Omed (Editors). Forage Evaluation in Ruminant Nutrition. CAB International Publishing (UK), pp. 301-320

Dhanoa M.S., 1988. On the analysis of dacron bag data for low degradability feeds. Grass Forage Sci. $43,441-444$

Dhanoa M.S., Lister S.J., France J., Barnes R.J., 1999. Use of mean square prediction error analysis and reproducibility measures to study near infrared calibration equation performance. J. Near Infrared Spectrosc. 7, 133-143

Huntington J.A., Givens D.I., 1995. The in situ technique for studying the rumen degradation of feeds: a review of the procedure. Nutr. Abstr. Rev., Ser. B 65, 63-93 
Kanski J., Kowalski Z.M., 2001. The use of NIRS for prediction of protein content in residues after incubation in the rumen. J. Anim. Feed Sci. 10, Suppl. 2, 363-367

Meng G.T., Ma C.Y., 2001. Fourier transform infrared spectroscopic study of globulin from Phaseolus angularis (red bean). Int. J. Biol. Macromol. 29, 287-294

Messman M.A., Weiss W.P., Koch M.E., 1994. Changes in total and individual proteins during drying, ensiling and ruminal fermentation in forages. J. Dairy Sci. 76, 1934-1944

Moya L., Garrido A., Guerrero J.E., Lizaso J., Gómez A., 1995. Quality control of raw materials in the compound feed industry. In: G. Batten, P.C. Flinn, L.A. Welsh, A.B. Blakeney (Editors). Leaping Ahead with Near 352 Infrared Spectroscopy. Royal Australian Chemical Institute, Melbourne (Australia), pp. 111-116

Reeves III J.B., Blosser T.H., Baldé A.T., Glenn B.P., Vandersall J., 1991. Near infrared spectroscopy analysis of forage samples digested in situ (nylon bag). J. Dairy Sci. 74, 2664-2673

SAS, 1988. SAS/STAT User's Guide, Version 6.03. SAS Institute Inc., Cary, NC

Williams P.C., 2001. Implementation of near-infrared technology. In: P.C. Williams, K. Norris (Editors). Near Infrared Technology in the Agricultural and Food Industries. American Association of Cereal Chemists, Minnesota (USA), pp. 145-169

Williams P.C., Sobering D.C., 1993. Comparison of commercial near infrared transmittance and reflectance instruments for analysis of whole grains and seeds. J. Near Infrared Spectrosc. 1, $25-32$

\section{STRESZCZENIE}

Czy metoda NIRS może być użyta do oszacowania in situ rozkładu bialka ogólnego i włókna detergentowego zielonek?

Metodę widma bliskiej podczerwieni (NIR) zastosowano do oszacowania współczynników degradacji białka ogólnego (CP) i neutralnego włókna detergentowego (NDF) 62 prób zielonek. Ponadto badano widmo NIR pozostałości po inkubacji prób uzyskanych w tym doświadczeniu, w celu oznaczenia ich składu chemicznego, a następnie obliczenia kinetyki i wskaźników degradacji NDF i CP. Wyniki otrzymane przy zastosowaniu tych dwóch różnych procedur można było porównać z wynikami otrzymanymi metodą „referencyjną” (analiza metodą „mokrą” pozostałości po inkubacji).

Najdokładniejsze wyniki uzyskano przy zastosowaniu widma NIR, przyjmując wyniki analiz chemicznych pozostałości po inkubacji. Jednakże mniej pracochłonne jest oznaczanie współczynników degradacji bezpośrednio na podstawie spektrum NIR oryginalnych prób zielonek. 